Прилози, Одд. мат. тех. науки, МАНУ, XXVII-XXVIII, 1-2 (2006-2007), стр. 31-39

Contributions, Sec. Math. Tech. Sci., MANU, XXVII-XXVIII, 1-2 (2006-2007), pp. 31-39

ISSN 0351-3246

UDC: $616.61-003.7-074$

\title{
CHEMOMETRIC EXAMINATION OF TRACE ELEMENTS ANALYSIS IN URINARY CALCULI
}

\author{
Violeta Petrova, Krste Tašev, Jožica Majda Bundaleska, \\ Igor Kuzmanovski, Trajče Stafilov, Mira Trpkovska
}

\begin{abstract}
A b s t r a c t: The content of $\mathrm{Pb}, \mathrm{Cd}, \mathrm{Ni}, \mathrm{Fe}, \mathrm{Na}$ and $\mathrm{K}$ was determined in sixteen samples of urinary calculi taken from patients in Macedonia. The trace elements were determined by atomic absorption spectrophotometry and by flame emission spectrometry. The chemometric examination of the calculi was done by factor analysis. This chemometric method has been extensively used for classification purposes while solving different multidimensional problems. The results obtained from the analysis revealed that the highest correlation exists between the concentrations of lead and potassium. No significant correlation among other analyzed elements was found. The examination of the first two principal components (with $67 \%$ variance captured) calculated from the autoscaled data matrix showed a clear separation between the composition of the calculi taken from male and from female patients, especially in the case of the calculi consisting of the two oxalates (whewellite and weddelite) and those composed of carbonate apatite in mixture with oxalates.
\end{abstract}

Key words: trace elements; urinary calculi, AAS, chemometry

\section{INTRODUCTION}

The urinary calculi have been extensively studied in our laboratory [16]. In the late sixties, the first statistical examination of the composition of urinary calculi in Macedonia was done using infrared spectroscopy as a tool for determining the composition of the calculi $[1,2,7]$. More recently, as a part of the studies of human concrements in our laboratory [3-6,8], it was possible to 
apply some more advanced chemometric techniques for determining the composition of the calculi [4-6] so that after some thirty years a new statistical examination of the qualitative composition of concrements taken from the patients from Macedonia [3] has been made.

In this work, we present the results of the chemometric treatment of data of trace elements analysis of sixteen urinary calculi by atomic absorption spectroscopy. Although there are literature data on the determination of trace elements in urinary calculi [9-16], we did not find any information about chemometric treatment of the data. In this work, the principal-component analysis $[17,18]$ (an extremely useful tool for the classification of samples according to some of their properties) was used to analyze the experimental data.

\section{EXPERIMENTAL}

\section{Instrumentation}

A Varian SpectrAA 640Z Zeeman atomic absorption spectrophotometer equipped with a Varian PSD-100 Autosampler was used for $\mathrm{Pb}, \mathrm{Cd}$ and $\mathrm{Ni}$ (Table 1), a Thermo Elemental Solaar S4 flame atomic absorption spectrophotometer for the determination of $\mathrm{Zn}$ and $\mathrm{Fe}$ (Table 2) and a JENWAY model PFP flame emission spectrometer was used for the determination of $\mathrm{Na}$ and $\mathrm{K}$. An Ethos Touch Control pressurized microwave digestion device (Milestone, Italy) with a rotor for 12 Teflon digestion vessels was used. To prevent explosions, the vessels are equipped with a pressure release system. A specially designed vessel which allows a temperature sensor and a pressure sensor to be connected and the progress of the digestion to be monitored, is substituted for one of the 12 vessels.

\section{Procedure}

Calculi samples weighing $0.5-1.0 \mathrm{~g}$ were placed in Teflon digestion vessels, $3 \mathrm{~mL}$ concentrated $\mathrm{HNO}_{3}$ and $2 \mathrm{~mL} \mathrm{H}_{2} \mathrm{O}_{2}(30 \%, \mathrm{~m} / \mathrm{V})$ were added, the vessels were capped closed, tightened and placed in the rotor of the microwave oven. The digestion was carried out with the digestion programs: $800 \mathrm{~W} / 15 \mathrm{~min}$; $1000 \mathrm{~W} / 25 \mathrm{~min}$ and a pressure of 20 bar. Finally the vessels were cooled, carefully opened and the digests quantitatively transferred to $25 \mathrm{~mL}$ calibrated flasks and filled up with redistilled water. $\mathrm{Fe}, \mathrm{Zn}, \mathrm{Na}$ and $\mathrm{K}$ were analyzed directly from these solutions. 
Ta b le 1

Instrumental parameters for trace element determination of $\mathrm{Cd}, \mathrm{Ni}$ and $\mathrm{Pb}$ by Zeeman ETAAS

\begin{tabular}{|c|c|c|c|}
\hline Parameter & $\mathrm{Cd}$ & $\mathrm{Ni}$ & $\mathrm{Pb}$ \\
\hline Wavelength/nm & 228.8 & 232.0 & 283.3 \\
\hline Spectral slit/nm & 0.5 & 0.2 & 0.5 \\
\hline Lamp current $/ \mathrm{mA}$ & 4.0 & 4.0 & 5.0 \\
\hline Calibration mode & \multicolumn{3}{|c|}{ Absorbance, peak height } \\
\hline Background correction & \multicolumn{3}{|c|}{ Zeeman } \\
\hline \multicolumn{4}{|l|}{ DRY } \\
\hline Temperature $/{ }^{\circ} \mathrm{C}$ & $85 ; 95 ; 120$ & $85 ; 95 ; 120$ & $85 ; 95 ; 120$ \\
\hline Ramp time/s & $5 ; 40 ; 5$ & $5 ; 40 ; 5$ & $5 ; 40 ; 5$ \\
\hline Hold time/s & 10 & 10 & 10 \\
\hline \multicolumn{4}{|l|}{ PYROLISIS } \\
\hline Temperature $/{ }^{\circ} \mathrm{C}$ & 600 & 900 & 800 \\
\hline Ramp time/s & 40 & 10 & 10 \\
\hline Hold time/s & 30 & 40 & 30 \\
\hline \multicolumn{4}{|l|}{ ATOMIZATION } \\
\hline Temperature $/{ }^{\circ} \mathrm{C}$ & 1800 & 2400 & 2100 \\
\hline Ramp time/s & 0.8 & 1.1 & 1 \\
\hline Hold time/s & 2 & 2 & 2 \\
\hline \multicolumn{4}{|l|}{ CLEANING } \\
\hline Temperature $/{ }^{\circ} \mathrm{C}$ & 1800 & 2400 & 2100 \\
\hline Hold time/s & 2 & 2 & 2 \\
\hline Gas & & Argon & \\
\hline
\end{tabular}

Прилози, Одд. мат. тех. науки, XXVII-XXVIII, 1-2 (2006-2007), стр. 31-39 
T a b 1 e 2

Instrumental parameters for determination of Fe and Zn by FAAS

\begin{tabular}{lcc}
\hline \hline Parameter & $\mathrm{Fe}$ & $\mathrm{Zn}$ \\
\hline Wavelength/nm & 248.3 & 213.9 \\
Spectral slit/nm & 0.2 & 1.0 \\
Lamp current/mA & 20 & 5 \\
\hline \hline
\end{tabular}

For $\mathrm{Pb}, \mathrm{Cd}$ and $\mathrm{Ni}$ an extraction method [19] was applied to eliminate the influence of $\mathrm{Ca}$ and $\mathrm{Mg} .5 \mathrm{~mL}$ of each sample solution were evaporated in a $100 \mathrm{~mL}$ glass beaker of to eliminate $\mathrm{HNO}_{3}$ and $\mathrm{H}_{2} \mathrm{O}_{2}$. After that, $1 \mathrm{~mL}$ of $\mathrm{HCl}$ and $15 \mathrm{~mL}$ of redistilled water were added and the solution was transferred into a separatory funnel. $5 \mathrm{~mL}$ of ammonium citrate solution $(50 \% \mathrm{~m} / \mathrm{V})$ were added and the $\mathrm{pH}$ value was adjusted with $\mathrm{NaOH}(20 \%, \mathrm{~m} / \mathrm{V})$ to 6 . Then, $5 \mathrm{~mL}$ of sodium diethyldithiocarbamate $(0.2 \%, \mathrm{~m} / \mathrm{V})$ were added and the mixture was shaken for $1 \mathrm{~min}$. After $15 \mathrm{~min}, 5 \mathrm{~mL}$ of methyl isobutyl ketone were added and the mixture was shaken for $2 \mathrm{~min}$. In the organic layer, the contents of cobalt, copper, lead and nickel were determined by electrothermal atomic absorption spectrometry (ETAAS).

\section{RESULTS AND DISCUSSION}

In order to examine how many factors have an influence on the results, the data presented in Table 3 were subjected to principal component analysis (PCA). The central idea of PCA is to reduce the dimensionality of the data set, explaining the variance-covariance structure $[17,18]$. This is achieved by linear transformation of the original data, usually into smaller number of uncorrelated significant principal components (PCs). Geometrically, the transformation represents the rotation of the original coordinate system in the direction of the maximum residual variance given by the first PC axis. The second PC, orthogonal to the first one, has the second maximum variance and so on. In this way, the projections preserving the maximum variance in the data sets can be visualized by computer.

In this work PCA was used in order do find possible grouping in the analyzed data. Before the data matrix was decomposed, the variables were autoscaled. The eigenvalues obtained by the decomposition of the data matrix are presented in Table 4. 
T a b l e 3

The content of $\mathrm{Na}, \mathrm{K}, \mathrm{Fe}, \mathrm{Zn}, \mathrm{Pb}, \mathrm{Ni}$ and $\mathrm{Cd}$ in the investigated calculi samples

\begin{tabular}{|c|c|c|c|c|c|c|c|c|c|c|}
\hline No. & $\begin{array}{l}\text { No. of the } \\
\text { calculi in [3] }\end{array}$ & $\begin{array}{l}\text { Type of } \\
\text { the calculi }\end{array}$ & $\begin{array}{l}\text { Sex of the } \\
\text { patients }\end{array}$ & $\frac{\mathrm{Na}}{\mathrm{mg} / \mathrm{g}}$ & $\frac{\mathrm{K}}{\mathrm{mg} / \mathrm{g}}$ & $\begin{array}{c}\mathrm{Fe} \\
\mu \mathrm{g} / \mathrm{g}\end{array}$ & $\begin{array}{c}\mathrm{Zn} \\
\mu \mathrm{g} / \mathrm{g}\end{array}$ & $\frac{\mathrm{Pb}}{\mu \mathrm{g} / \mathrm{g}}$ & $\begin{array}{c}\mathrm{Ni} \\
\mu \mathrm{g} / \mathrm{g}\end{array}$ & $\frac{\mathrm{Cd}}{\mathrm{ng} / \mathrm{g}}$ \\
\hline 1 & 23 & oc & Female & 9.43 & 3.14 & 4.93 & 459.05 & 0.88 & 0.31 & 7.75 \\
\hline 2 & 24 & oc & Male & 4.40 & 1.19 & 5.20 & 44.04 & 1.52 & 0.34 & 7.09 \\
\hline 3 & 25 & ox & Male & 0.12 & 0 & 24.44 & 52.89 & 2.38 & 0.36 & 8.77 \\
\hline 4 & 26 & oc & Female & 8.21 & 3.23 & 16.30 & 198.40 & 1.22 & 9.54 & 3.04 \\
\hline 5 & 27 & st & Female & 1.32 & 1.66 & 1.79 & 829.4 & 2.05 & 0.20 & 3.27 \\
\hline 6 & 34 & oc & Male & 8.97 & 1.45 & 9.24 & 745.21 & 2.25 & 0.56 & 8.36 \\
\hline 7 & 36 & ua & Male & - & 0.20 & 5.52 & 6.82 & 5.48 & 0.90 & 26.80 \\
\hline 8 & 38 & oc & Female & 1.53 & 0.06 & 17.60 & 924.39 & 3.46 & 0.36 & 6.14 \\
\hline 9 & 39 & oc & - & - & - & 12.55 & 744.95 & 1.91 & 3.53 & 21.18 \\
\hline 10 & 43 & ox & Male & 14.39 & - & 17.15 & 24.86 & 2.92 & 0.97 & 32.16 \\
\hline 11 & 47 & ox & Male & 0.28 & 0.56 & 7.47 & 538.07 & 1.86 & 0.23 & 70.40 \\
\hline 12 & 48 & oc & Male & - & - & 22.51 & 278.35 & 4.09 & 1.27 & 14.78 \\
\hline 13 & 74 & st & Male & 14.97 & 0.16 & 15.61 & 107.08 & 2.93 & 0.64 & 9.61 \\
\hline 14 & - & - & - & 0.80 & 1.77 & 5.20 & 152.51 & 2.69 & 0.24 & 5.75 \\
\hline 15 & - & - & - & 26.77 & 0.32 & 10.26 & 59.06 & 1.88 & 0.42 & 3.51 \\
\hline 16 & - & - & - & - & 4.06 & 10.19 & 22.64 & 1.45 & 0.32 & 9.45 \\
\hline
\end{tabular}

Types of calculi: oc - oxalates and carbonate apatite, ox - calcium oxalates, st - struvite, ua - uric acid

$\mathrm{T}$ a b l e 4

Eigenvalues (EV), percentage variance (PV) and cumulative percentage variance $(C P V)$ calculated from preprocessed data matrix

\begin{tabular}{cccc}
\hline \hline № & EV & PV & CPV \\
\hline 1 & 4.038 & 43.65 & 43.65 \\
2 & 2.159 & 23.34 & 66.99 \\
3 & 1.329 & 14.36 & 81.35 \\
4 & 0.759 & 8.20 & 89.55 \\
5 & 0.691 & 7.47 & 97.02 \\
6 & 0.248 & 2.68 & 99.69 \\
7 & 0.028 & 0.31 & 100.00 \\
\hline \hline
\end{tabular}

Прилози, Одд. мат. тех. науки, XXVII-XXVIII, 1-2 (2006-2007), стр. 31-39 
Table 4 shows that almost $90 \%$ of the variance could be explained by the first four principal components. This means that four factors could be considered as influencing our data. 2D and 3D examination of the scores matrix calculated by decomposition of the preprocessed data matrix did not present significant information about possible correlations among the variables (the concentrations of the analyzed elements). In our case, more informative was the correlation matrix presented in Table 5 which shows that the highest correlation among of concentrations of $\mathrm{Pb}$ and $\mathrm{K}$ is -0.608 .

$\mathrm{Tab} l$ e 5

Correlation matrix

\begin{tabular}{cccccccc}
\hline \hline & $\mathrm{Fe}$ & $\mathrm{Zn}$ & $\mathrm{Pb}$ & $\mathrm{Ni}$ & $\mathrm{Cd}$ & $\mathrm{Na}$ & $\mathrm{K}$ \\
\hline $\mathrm{Fe}$ & 1 & & & & & & \\
$\mathrm{Zn}$ & -0.158 & 1 & & & & & \\
$\mathrm{~Pb}$ & 0.228 & -0.118 & 1 & & & & \\
$\mathrm{Ni}$ & 0.253 & -0.025 & -0.22 & 1 & & & \\
$\mathrm{Cd}$ & -0.059 & 0.041 & 0.153 & -0.131 & 1 & & \\
$\mathrm{Na}$ & 0.026 & -0.273 & -0.221 & 0.032 & -0.323 & 1 & \\
$\mathrm{~K}$ & -0.379 & -0.074 & -0.608 & 0.277 & -0.209 & -0.088 & 1 \\
\hline \hline
\end{tabular}

More significant information was obtained by plotting PC1 and PC2 from the loadings matrix (Fig. 1). From this figure (Fig 1a) it is possible to see the grouping of the calculi samples taken from the male patients in the left and the upper part of the figure, while the stones taken from female patients are grouped at the bottom. In Fig. $1 \mathrm{~b}$ it can be noted that the phosphate containing calculi are mainly grouped in the lower part of the figure, while the rest of the calculi are grouped in the upper part.

The present analysis seems to show that the content of the trace elements depends on the composition of the calculi and the sex of the patients, although a similar examination obtained with a larger sample could lead to more reliable results. At present we are not able to determine which factors mainly influence the content of the analyzed trace elements in the concrements. In order to find information about this, a more detailed medical examination of the factors influencing the formation of the calculi and the incorporation of the trace elements in them should be considered. 

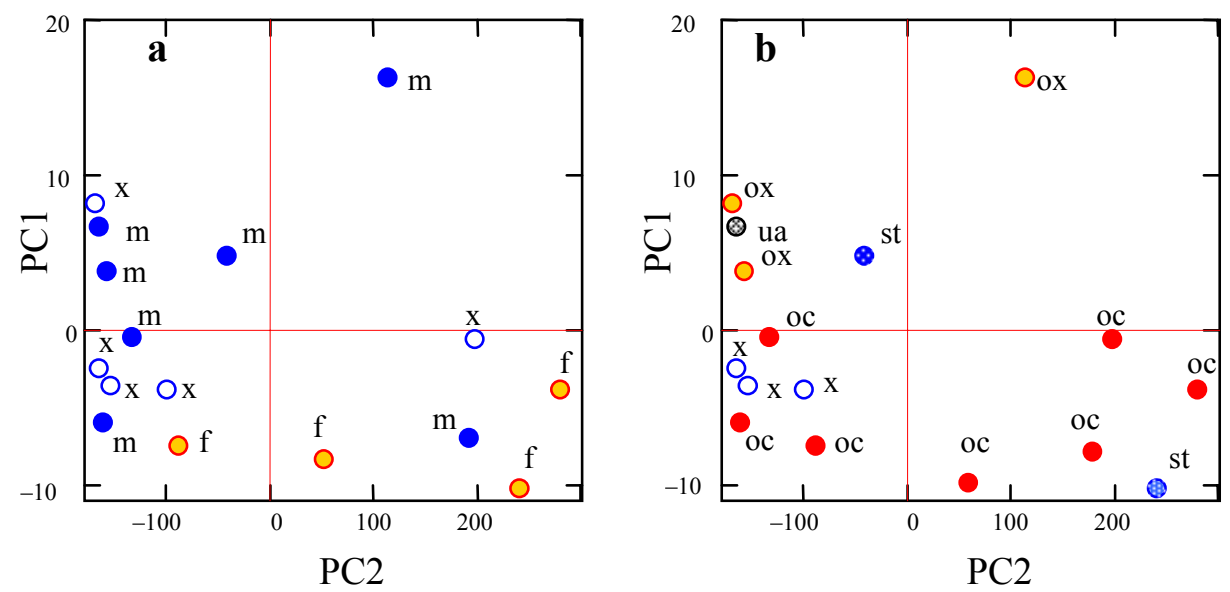

Fig. 1. Principal component analysis on 16 samples using 7 variables. a - labeled with the sex of the patients ( $m$ - male, $f$ - female, $x$ - unknown); $b$ - labeled with the composition of the samples (oc - oxalates and carbonate apatite, ox - oxalates, st - struvite, ua - uric acid, $\mathrm{x}$ - unknown)

\section{REFERENCES}

[1] K. Stojanova, I. Petrov, B. Šoptrajanov. Yugoslav. Phisiol. Pharmacol. Acta, 5, 137 (1969).

[2] К. Стојанова, И. Петров, Б. Шоптрајанов, Макед. мед. иирег̄лед, 24, 71 (1969).

[3] И. Кузмановски, М. Трпковска, Б. Шоптрајанов, Макед. мед. иирег̄лед, 53, 251 (1999).

[4] I. Kuzmanovski, M. Trpkovska, B. Šoptrajanov, V. Stefov, Vib. Spectrosc., 19, 249 (1999).

[5] I. Kuzmanovski, Z. Zografski, M. Trpkovska, B. Šoptrajanov, V. Stefov, Fresenius' J. Anal. Chem., 370, 919 (2001).

[6] I. Kuzmanovski, M. Trpkovska, B. Šoptrajanov, V. Stefov, Anal. Chim. Acta, 491, 211 (2003).

[7] N. Q. Dao, M. Daudon, Infrared and Raman Spectra of Calculi, Elsevier, Paris, 1997.

[8] I. Kuzmanovski, M. Ristova, B. Šoptrajanov, V. Stefov, V. Popovski, Talanta, 62, 813 (2004).

[9] I. Durak, A. Yasar, Z. Yurtarslan, M. Akpoyraz, S. Tasman, Br. J. Urol., 62, 203 (1988).

[10] J. B. Smith, C. Thevenon-Emeric, D. L. Smith, B. Green, Anal. Biochem., 193, 118 (1991).

[11] I. Durak, Turk. J. Med. Sci., 17, 93 (1993).

[12] S. Pevez, G. S. Pandey, Environ. Monit. Assess., 32, 93 (1993).

Прилози, Одд. мат. тех. науки, XXVII-XXVIII, 1-2 (2006-2007), стр. 31-39 
[13] K. Shirin, M. Qadiruddin, W.W.T. Manser, A.M. Syed, Pak. J. Sci. Ind Res., 37, 88 (1994).

[14] K. Kobarth, C. Koeberi, J. Hofbauer, Urol. Res., 21, 261 (1993).

[15] C. Koeberi, P. M. Bayer, K. Kobarth, J. Radioanal. Nucl. Chem., 169, 269 (1993).

[16] T. Umeyama, Y. Ogawa, Nippon, Hinyokika Gakkai Zasshi, 75, 1038 (1984).

[17] R. A. Johnson, D. W. Wichern, Applied Multivariate Statistical Analysis, PrenticeHall, New Jersey, 1982, p. 521.

[18] E. R. Malinowski, Factor Analysis in Chemistry, 2nd. Ed., Wiley, New York, 1991.

[19] T. Stafilov, D. Zendelovska, Acta Chim. Slov. 47, 381 (2000).

Р ез и м е

\section{ХЕМОМЕТРИСКО ИСПИТУВАҢЕ НА ЕЛЕМЕНТИ ВО ТРАГИ ВО УРИНАРНИ КАЛКУЛУСИ}

Во 16 уринарни калкулуси од пациенти од Македонија е определувана содржината на $\mathrm{Pb}, \mathrm{Cd}, \mathrm{Ni}, \mathrm{Fe}, \mathrm{Na}$ и K. Елементите во траги беа определувани со примена на атомска апсорпциона спектрометрија и со пламена емисиона спектрометрија. Извршена е хемометриска анализа на калкулусите со користење на факторната анализа. Овој хемометриски метод широко се применува за класификација на различни примероци, како и за решавање на други повеќедимензионални проблеми. Резултатите добиени со анализата на податоците покажуваат дека најголема корелација постои меѓу концентрациите на оловото и калиумот, додека меѓу концентрациите на другите елементи не беше најдена значителна корелација. Со разгледување на првите два карактеристични вектора пресметани од матрицата на автоскалирани податоци (овие вектори содржат 67\% од варијанцата), може да се забележи раздвојување меѓу калкулусите кои потекнуваат од пациенти мажи и оние од пациенти жени. Освен тоа, забележано е групирање на калкулусите создадени само од оксалати, од една страна, и калкулусите создадени од смеса на оксалати и карбонатен апатит, од друга.

Клучни зборови: елементи во траги; уринарни калкулуси; ААС; хемометрија

Adress:

Violeta Petrova

Institute of Chemistry, Faculty of Natural Sciences and Mathematics,

"SS. Cyril and Methodius" University, Skopje,

P. O. Box 162, MK-1001 Skopje, Republic of Macedonia

\section{Krste Tašev}

Institute of Chemistry, Faculty of Natural Sciences and Mathematics,

"SS. Cyril and Methodius" University, Skopje,

P. O. Box 162, MK-1001 Skopje, Republic of Macedonia

tkrste@gmail.com 


\section{Jožica Majda Bundaleska}

Institute of Chemistry, Faculty of Natural Sciences and Mathematics,

"SS. Cyril and Methodius" University, Skopje,

P. O. Box 162, MK-1001 Skopje, Republic of Macedonia

jozica@hotmail.com

\section{Igor Kuzmanovski}

Institute of Chemistry, Faculty of Natural Sciences and Mathematics, "SS. Cyril and Methodius" University, Skopje,

P. O. Box 162, MK-1001 Skopje, Republic of Macedonia

Igor.Kuzmanovski@ki.si

\section{Trajče Stafilov}

Institute of Chemistry, Faculty of Natural Sciences and Mathematics,

"SS. Cyril and Methodius" University, Skopje,

P. O. Box 162, MK-1001 Skopje, Republic of Macedonia

trajcest@iunona.pmf.ukim.edu.mk

\section{Mira Trpkovska}

Institute of Chemistry, Faculty of Natural Sciences and Mathematics,

"SS. Cyril and Methodius" University, Skopje,

P. O. Box 162, MK-1001 Skopje, Republic of Macedonia

mirat@iunona.pmf.ukim.edu.mk

Received: 4. III 2005

Accepted: 1. IV 2005

Прилози, Одд. мат. тех. науки, XXVII-XXVIII, 1-2 (2006-2007), стр. 31-39 